\title{
SELF-DETERMINATION OF THE FUTURE DOCTORS FROM THE POINT OF CYBERNETIC APPROACH
}

\section{Tetiana Kocharova ${ }^{1}$}

\section{DOI: https://doi.org/10.30525/978-9934-588-39-6-9}

The essence of pedagogical interaction is the direct or indirect influence of the subjects of this process on each other, which gives rise to their mutual connection. Therefore, the student is not only the object of learning that exists under the influencing and specific requirements or suggestions, but it is the subject of a learning process that is able to influence other students.

The analysis of the subjects of educational activity, which includes two interrelated forms - pedagogical and educational, is in line with both philosophical and specifically pedagogical tasks. S.L. Rubinstein defines a subject as a conscious actor [1, p. 335] that in acts of his amateur creative activity, not only manifests himself; but it is created and determed in them» [1, p. 172].

In this context, a cybernetic approach may be used to consider the concept of subject, object, and interaction between them. Thus, from the standpoint of cybernetics, learning is regarded as an information process in the learning system, characterized by the management of channels of direct and feedback, the development and change of strategies, programs and algorithms [2, p. 77].

The cybernetic approach in the educational process was previously considered by the authors mainly in the context of the interpretation of feedback in knowledge control [3, p. 120]. But in this situation the student ceases to be an equal subject and is given the properties of the object.

In order to assist students in self-determination as an active part of educational and professional activity, a method of seminar lesson on a certain topic that has analogies with the process of communication was developed.

In accordance with the work program and the manual on the discipline «Medical Informatics» this class includes the study of basic concepts of cybernetics, the consideration of physiological, medical and biological trends in cybernetics.

At the beginning of the class, a teacher provides introductory information explaining the theoretical background below.

Cybernetics studies the laws of functioning of a special kind of systems, which are closely related to the concept of control.

\footnotetext{
${ }^{1}$ Kharkiv National Medical University, Ukraine
} 
The operation of cybernetic systems is based on the perception, storage, exchange and processing of information. Cybernetics is often called «management science». The founder of cybernetics is the American mathematician Norbert Wiener, who laid its theoretical foundations.

The basic concepts of cybernetic systems are: feedback and control. The concept of control is basic in cybernetics, because it defines the subject of study of this science.

Control - is the purposeful impact of one system (control subject) on another one (control object), which is chosen from the multitude of possible interactions on the basis of the current information and serves for the condition (behavior) change of a control object in accordance with changing conditions of the environment for its development and functioning improvement [4, p. 75].

The control subject produces control signals that perform management actions. The control subject is also called the control system and the control object is called the controlled system

Feedback is one of the basic concepts of cybernetics and signifies the influence of the output of the system on its operating parameters. Feedback provides self-regulation of the system, its adaptive management. Feedback can be negative and positive.

Negative feedback counteracts the tendency of change of the initial parameter, promotes its stabilization. Negative feedbacks provide stability of body functions, constancy of its parameters, resistance to external influences. On the principle of negative feedback, mechanisms of thermoregulation of all living creatures work.

Positive feedback, on the contrary, keeps the trends of the initial parameters of the system.

Under the influence of control effects, the system (object) assumes a better (in some sense) state than in the absence of control effects.

During the seminar discussion the author distinguished certain commonalities that integrate the concepts of control, coexistence of organism systems and communication process.

In almost every process of communication between people a subject of communication can be identified. It is an individual, who organizes the process of mutual interaction with a character with his or her own choice, a partner, and is aimed at reconciling intentions and identifying relationships. A subject produces directives that modify the actions of an object.

The role of the subject in various cases is also fulfilled by the local environment, teachers or parents who exercise influence or control. Then the student's personality temporary becomes a object. 
The terminology of the basics of cybernetics as a management science is identified by the pattern of human relations discussed during the workshop in the following aspect:

The subject produces directives that change the actions of the object its role in various situations is performed by the student or his environment, which exercise influence or control.

The external environment is a changing world that creates the conditions for the existence of an object.

Feedback - under the influence of a subject, an object can change behavior and adapt to conditions that are positive feedback. Or it can retain its personality, overcoming the influence of the subject.

Each of these behaviors has good and bad consequences, which are given in individual life examples.

During the seminar student relationships their relationship with the family, adaptation to the local environment, identifies the country of origin are discussed, wich establishes a certain atmosphere of trust through discussion of national and personal customs.

Also, according to the chosen method, students are educated, namely: bad habits are recalled in the context of decision making under the influence of the other party.

In parallel, within the medical orientation of the discipline, some examples of coexistence of organism systems that correspond to the considered concepts are emphasized. For example, the physiology of the influence of alcohol on an maladapted organism under the influence of cold is considered.

As the result, the education acts, on the one hand, as an emotional process of communication, on the other - as a direct meaningful characteristic of relationships. It can be said that it is a creative process, both in terms of decision-making of educational tasks and in terms of organizing relationships.

Thus, the discussion of life situations achieves the professional purpose of the lesson on mastering the basics of cybernetics and establishes certain trusting relationships between students and the teacher, also the communicative, psychological and cognitive functions of pedagogical communication are realized.

\section{References:}

1. Rubinshtejn, S. L. (2015). Osnovy obshej psihologii [Fundamentals of General Psychology]. Sankt-Peterburg: Piter. (in Russian)

2. Shveenkov, D. G. (2014). Student kak subyekt pedagogicheskogo kontrolya $v$ sovremennoj vysshej shkole [Student as a subject of pedagogical control in modern higher education]. Krasnodar: ASPECTUS, no 1, pp. 76-83. (in Russian) 
3. Egorov, V. V., Skibickij, E. G., \& Hrapchenkov, V. G. (2008). Pedagogika vysshej shkoly: Uchebnoe posobie [Higher Education Pedagogy: Study Guide]. Novosibirsk: SAFBD. (in Russian)

4. Knigavko, V. G. (ed.) (2017). Biological, medical and physiological cybernetics. Medical information science: textbook for 2nd year students of medical universities. Kharkiv: KhNMU, pp. 74-82.

\section{IMPACT OF VOLONTEERING ON FUTURE PE TEACHERS’ PATRIOTIC EDUCATION}

\section{Inna Kurlishchuk ${ }^{1}$ Yurii Poluliashchenko ${ }^{2}$}

DOI: https://doi.org/10.30525/978-9934-588-39-6-10

Throughout the history of Ukraine, the system of Higher Education has been called upon to shape patriotic education of university student youth, in particular to form and share social knowledge, political, civic and moral attitudes towards different community and state problems; to improve citizen's pro-social behavior and civic mindedness; to foster personal tollerance and understanding the cultural differences among members of Ukrainian society that are belong to multivariately viewed social groups as well as to support community cohesion. Under modern social and political conditions in our country that are characterized by the strong focus on European integration and values, the problem of preserving national identity, the uniqueness of Ukrainian historical and cultural heritage by the means of patriotic education of university student youth becomes relevant.

Today one of the most important problems of the system of Ukrainian Higher Education is the improvement of context and modernization of professional training of teachers and, especially future PE teachers who have the greatest influence on spiritual and physical health of a new patriotic oriented generation of Ukrainians. The problem of patriotism formation of future PE teachers required further comprehensive study.

In pedagogical, psychological and social theory and practice a considerable number of researches on the issue of university students' patriotic education have been conducted (I. Bekh, M. Boryshevskyi, K. Chorna, L. Chuprii, O. Savchenko, M. Yevtukh, O. Zharovska, K. Zhurba,

\footnotetext{
${ }^{1}$ Luhansk Taras Shevchenko National University, Ukraine

${ }^{2}$ Luhansk Taras Shevchenko National University, Ukraine
} 